Yunfei Du; Ming Zhu

University of North Texas; Yunnam University

Yunfei.du@unt.edu; zhum@ynu.edu.cn

\title{
Investigation and Analysis of the Current Status of School Libraries in China
}

\begin{abstract}
Based on the surveys and the analysis of 72 school libraries in 6 provinces in 3 regions of China, this study found that although the development of school libraries in China has started, the core values and concepts of the school library services have not been reflected in its overall practice, and library infrastructure, services, and librarians' credentials and school libraries' digital resources have not improved significantly. There is a gap among school libraries between the economically developed eastern region and the poorer western regions, suggesting a more serious question of imbalance of school library services.

Keywords: China, school library, school librarians, credentials, library infrastructure

\section{Introduction}

Technology and globalization have led the interconnections among markets and nations, and individuals, companies, and nation-states to reach around a world that is "flattened" with less boundaries among talent and workforce exchange (Steward, 2012). It is well accepted that education is one of the best tools to empower the next generation of workforce with literacy skill, critical thinking, inclusion, creativity, and teamwork. In this context, the school library contributes to the mission of education, the building of the learning communities and the opportunity for all students to learn and grow. The school library is the entity and digital learning space of the school, in which students experience the transformation of information to knowledge and obtain personal, social and cultural growth through reading, inquiry, research, thinking, imagination and creation.
\end{abstract}

At present, the reform of the primary and secondary education in China is gradually taking place, including curriculum innovation and quality enhancement efforts award challenges and opportunities for Chinese school libraries. However, school library professional standards have not been fully established yet, and little is known how local administrators and stakeholders put forward standards and requirements for school library operations. To fill the gap on Chinese school library research, this paper reports on the survey of 72 school libraries in China in order to investigate its status, and provides suggestions for the future. 
Chinese universities almost solely rely on students' national college entrance exam scores as the admission criteria, and schools tend to allocate all education resources preparing for exams. To many school administrators, school library development is the secondary matter. In addition, local-level school library professional organizations are scarce, hindering the research of primary and school libraries in China.

As a first step, this paper intends to study the current status of school libraries in China. These are the research questions:

Q1. What is the status of school library facilities in China?

Q2. What services do school libraries provide in China?

Q3. What are school librarians' professional credentials in China?

Q4. What is the status of digital resources of school libraries in China?

\section{Literature Review}

Hartzell (2002) emphasized the importance of school administrators' perceptions on school librarians and the library profession, and the shift of advocacy approach from local level to university educational administration professors and the professional associations for administrators (2012). Same principle may also apply to Chinese school libraries.

The development of school libraries in China started late, due to the long-term influence of test-oriented education. Since the funding, ranking, and even the survival of schools depends on students' graduation and college admission rates, school libraries that often play minor roles in test-preparation are often ignored by administrators. Most of the research on China's school libraries are small scale research reports, such as Miao's (1991) introduction of the development of China's primary and middle-school libraries. In recent years, China's school library has begun to receive the attention of researchers. Wei, Jiang, \& Niu (2013) presented a case study of school library programs in two rural counties in western China, and reported high schools that took a series of outreach initiatives to improve local residents' access to information and addressed their cultural and educational needs.

Zhang, Wang, \& Ji (2016) used a survey approach to examine the collections and services of school libraries in the city of Guangzhou, China, and found that the collections and services varied significantly between schools, where enrollment types (elementary, middle, junior high, etc), and school location (urban, suburban, and rural), student boarding/commuting status were three leading factors contributing to the differences.

Zhang, Lin, \& Madden (2019) responded to the IFLA's school library guidelines by surveying school librarians in south China. Most respondents considered recommended guidelines applicable, but several areas were considered poorly suited to the Chinese situation. Participants felt that some elements were politically insensitive, and that the lack of degreed school librarians in China would make some impractical. 
Yi, Mo, \& Wang (2019) used a randomized controlled trial of 11,083 fourth- and fifth-grade students in 120 primary schools in rural China to examine the causal effect of an in-class library program on student reading outcomes and academic achievement in schools with poor reading resources over an eight-month period. They found that the program significantly improved student affinity toward reading and student reading habits, and in these regards, it narrowed the gap between male and female students, between low- and high-performing students, and between left-behind children and children living with parents.

Overall, since 2015, China's school library has begun to receive the attention of researchers, there have been preliminary discussions on China's school library policies, service standards, and reading literacy, et al., but there is no regional or national research on the current status of China's school libraries. This paper tried to bridge the gap in this area by surveying school librarians across the country.

\section{Methodology}

To ensure the representation of the samples, this paper divided the Chinese provincial administrative units in three regions according to the level of economic development and the level of educational investment in general, and for each region two provinces were randomly selected. The first region included coastal Jiangsu Province and Zhejiang Provinces. Hunan Province and Jiangxi Province represented the second region. And the third region is delegated by Yunnan Province and Guizhou Province. In each province, a stratified sampling of the school libraries surveyed was taken, from each Province we selected 12 school libraries, and a total of 72 school libraries were sampled for the survey.

Data were collected through questionnaires, e-mails and telephone interviews to the librarians of the school libraries. The questionnaire consists of four parts (library facilities, services, librarian's credentials, and library collections). Data was analyzed through SPSS 30.0 software.

\section{Findings}

To answer the four research questions, the next section describes the status of school library facilities, library services provided, followed by demographics of librarians and professional credentials, and digital and print resources available in these 72 school libraries.

\subsection{School Library Facilities}

The library facilities are reflected by library space, reading room seats, building status, and number of collections per student. In all three regions, $10.8 \%$ of school libraries have a space of more than $800 \mathrm{~m}^{2}$, and $24.4 \%$ are in a space less than $100 \mathrm{~m}^{2}$. However, more western region libraries are smaller, with $30.3 \%$ of them being smaller than $100 \mathrm{~m}^{2}$, compared to only $10.5 \%$ in eastern region. $22.9 \%$ of eastern region school libraries are above $800 \mathrm{~m}^{2}$, and only $3.4 \%$ of western region libraries have such space. As for the number of reading room seats, in general $19.7 \%$ of the reading rooms in all three regions have 10 seats or below. However, in the eastern 
region libraries, only $6.2 \%$ are that small, compared to $42.3 \%$ western libraries having 10 seats or below. $36.3 \%$ of school libraries in the eastern region have reading seats more than 40 , but this number in the central western regions accounted for only $8.2 \%$ and $6.7 \%$.

On library buildings, $54.1 \%$ of school libraries in the three regions do not have independent buildings on campus, while $68.4 \%$ of the libraries in the eastern region are in independent buildings on campus, $40.9 \%$ school libraries in the central region are so, and only $27.5 \%$ school libraries in the western region have independent buildings on campus. In easter region, only $4.2 \%$ of schools have 10 books or less per person, but that $40.1 \%$ schools in the central region and $38.9 \%$ in the western region libraries have that small number of books per person. At the same time, $41.2 \%$ of school libraries in the eastern region have a collection of more than 40 books per person, while the number for the central and western school libraries are $8.9 \%$ and $7.5 \%$, respectively. Table 1 illustrated detailed library statistics.

Table 1

\section{Library Statistics}

\begin{tabular}{|c|c|c|c|c|c|}
\hline $\begin{array}{l}\text { Survey } \\
\text { projects }\end{array}$ & Index & $\begin{array}{c}\text { Eastern } \\
\text { region ( \%) }\end{array}$ & $\begin{array}{c}\text { Central region } \\
(\%)\end{array}$ & $\begin{array}{c}\text { Western } \\
\text { Region ( \%) }\end{array}$ & $\begin{array}{c}\text { Cumulative } \\
(\%)\end{array}$ \\
\hline \multirow{5}{*}{$\begin{array}{l}\text { Library } \\
\text { Spaces }\end{array}$} & $100 \mathrm{~m}^{2}$ & 10.5 & 32.5 & 30.3 & 24.4 \\
\hline & 101 to $400 \mathrm{~m}^{2}$ & 10.4 & 24.3 & 33.1 & 22.6 \\
\hline & 401 to $600 \mathrm{~m}^{2}$ & 28.9 & 22.1 & 20.8 & 23.9 \\
\hline & 601 to $800 \mathrm{~m}^{2}$ & 27.3 & 18.2 & 12.4 & 19.3 \\
\hline & Above $800 \mathrm{~m}^{2}$ & 22.9 & 6.2 & 3.4 & 10.8 \\
\hline \multirow{5}{*}{$\begin{array}{l}\text { Number of } \\
\text { Seats in the } \\
\text { Reading } \\
\text { Room }\end{array}$} & 10 & 6.2 & 10.7 & 42.3 & 19.7 \\
\hline & 11 to 20 & 8.3 & 21.2 & 22.9 & 17.5 \\
\hline & 21 to 30 & 21.2 & 30.3 & 16.4 & 22.6 \\
\hline & 31 to 40 & 28.9 & 29.6 & 11.7 & 23.4 \\
\hline & Above 40 & 36.3 & 8.2 & 6.7 & 17.1 \\
\hline \multirow{2}{*}{$\begin{array}{c}\text { Library is an } \\
\text { Independent } \\
\text { Building }\end{array}$} & Yes & 68.4 & 40.9 & 27.5 & 45.6 \\
\hline & No & 30.7 & 59.1 & 72.5 & 54.1 \\
\hline \multirow{5}{*}{$\begin{array}{l}\text { Number of } \\
\text { Collections } \\
\text { Per person }\end{array}$} & 10 & 4.2 & 40.1 & 38.9 & 27.7 \\
\hline & 11 to 20 & 6.8 & 28.8 & 23.5 & 19.7 \\
\hline & 21 to 30 & 22.8 & 18.9 & 17.3 & 19.7 \\
\hline & 31 to 40 & 25 & 11.3 & 12.8 & 16.4 \\
\hline & Above 40 & 41.2 & 8.9 & 7.5 & 19.2 \\
\hline
\end{tabular}




\subsection{School Library Services}

The school services reflect the ability of the school libraries to support teachers and students in learning. For the library card, school libraries in the three regions offered library cards for teachers and students accounted for $57.3 \%$. This number from the eastern region libraries reached $83.6 \%$, but the central region is $51.8 \%$, and $26.4 \%$ of the school libraries in the western region did offer a library card for teachers and students.

Regarding the average annual number of books that students and teachers checked out, $62.4 \%$ of school libraries in the three regions borrowed less than 25 books, and the number is $56.2 \%$ in the eastern region, $62.4 \%$ in the central region, and $68.6 \%$ in the western region. In terms of weekly opening hours of school libraries, $49.7 \%$ of school libraries in the three regions have weekly opening hours less than 40 hours. $82.5 \%$ of school libraries in the eastern regions open more than 40 hours per week, $36.3 \%$ in the central region, and $32.2 \%$ in the western region.

Regarding information literacy education in school libraries, $83.9 \%$ of the school libraries in the three regions did not have information literacy education for students, but $35.1 \%$ of the school libraries in the eastern region offer information literacy education for students, and $13.2 \%$ in the central region, and none in the western region offer information literacy education for students. On Average $42.9 \%$ schools carried out reading promotion service, but that number is $58.3 \%$ in the eastern region, $45.5 \%$ in the central region, and only $24.9 \%$ in the western region. Table 2 illustrates detailed statistics on library services.

Table 2

Statistics on Library Services

\begin{tabular}{|c|c|c|c|c|c|}
\hline $\begin{array}{c}\text { Survey } \\
\text { projects }\end{array}$ & Index & $\begin{array}{c}\text { Eastern region } \\
(\%)\end{array}$ & $\begin{array}{c}\text { Central region } \\
(\%)\end{array}$ & $\begin{array}{c}\text { Western } \\
\text { Region }(\%)\end{array}$ & $\begin{array}{c}\text { Cumulative } \\
(\%)\end{array}$ \\
\hline $\begin{array}{c}\text { Library card } \\
\text { to teachers } \\
\text { and students }\end{array}$ & Yes & 83.6 & 61.8 & 26.4 & 57.3 \\
\cline { 2 - 6 } & No & 16.4 & 38.2 & 73.6 & 42.7 \\
\hline \begin{tabular}{c} 
Aver. \# of \\
books per \\
person per \\
\cline { 2 - 6 } year
\end{tabular} & $>25$ & 56.2 & 62.4 & 68.6 & 62.4 \\
\hline $\begin{array}{c}\text { Opening } \\
\text { hours per } \\
\text { week }\end{array}$ & $>40$ & 83.8 & 37.6 & 31.4 & 37.6 \\
\cline { 2 - 6 } & $>40$ & 17.5 & 63.7 & 67.8 & 49.7 \\
\hline
\end{tabular}




\begin{tabular}{|c|c|c|c|c|c|}
\hline $\begin{array}{c}\text { Information } \\
\text { literacy } \\
\text { education }\end{array}$ & Yes & 35.1 & 13.2 & 0 & 16.1 \\
\cline { 2 - 6 } & No & 64.9 & 86.8 & 100 & 83.9 \\
\hline $\begin{array}{c}\text { Reading } \\
\text { promotion } \\
\text { activities }\end{array}$ & Yes & 58.3 & 45.5 & 24.9 & 42.9 \\
\cline { 2 - 6 } & No & 41.7 & 54.5 & 75.1 & 57.1 \\
\hline
\end{tabular}

\section{3 Librarians'Professional Credentials}

Professional credentials reflect the quality of library services. In terms of the number of full-time librarians in the libraries, $24.3 \%$ of libraries in the three regions have 2 or less full-time librarians are below, and $50.1 \%$ have 2 to 4 librarians, and $25.6 \%$ have more than 4 librarians. As for the educational level of full-time librarians, $19.4 \%$ of the librarians in all three regions graduated from high school, 33.9\% have a college degree, and 10.9\% have a master's degree. However, western region, $32.5 \%$ of librarians graduated from high school, $24.2 \%$ had a college degree, and only $3.1 \%$ had a master's degree. For the age distribution of librarians, $24.3 \%$ of librarians were under the age of 35 in the three regions, 39\% were between the ages of 35 and 50, and $41.6 \%$ were older than those aged 50. As for professional education, $81.1 \%$ of librarians in all 3 regions do not have a library science degree. Regarding whether the library has a full-time director or curator, only $13.6 \%$ of the school libraries in the three regions have full-time directors, and in the west region, there is no full time director in the school library. Table 3 illustrates library professional credentials and statistics.

Table 3

Library Professional Credentials and Statistics

\begin{tabular}{|l|l|l|l|l|l|}
\hline \multirow{2}{*}{ Survey Item } & Index & $\begin{array}{l}\text { Eastern } \\
\text { region ( \%) }\end{array}$ & $\begin{array}{l}\text { Central } \\
\text { region ( \%) }\end{array}$ & $\begin{array}{l}\text { Western } \\
\text { Region ( \%) }\end{array}$ & $\begin{array}{l}\text { Cumulative } \\
(\%)\end{array}$ \\
\hline $\begin{array}{l}\text { Number of } \\
\text { full-time } \\
\text { librarians }\end{array}$ & $<2$ & 12.3 & 29.2 & 31.4 & 24.3 \\
\cline { 2 - 6 } & 2 to 4 & 42.5 & 54.6 & 53.3 & 50.1 \\
\hline \multirow{3}{*}{$\begin{array}{l}\text { Educational } \\
\text { level }\end{array}$} & High school & 8.7 & 16.2 & 15.3 & 25.6 \\
\cline { 2 - 6 } & $\begin{array}{l}\text { Bachelor } \\
\text { degree }\end{array}$ & 45.4 & 32.2 & 32.5 & 19.4 \\
\cline { 2 - 6 } & Master degree & 20.1 & 9.5 & 3.1 & 33.9 \\
\hline \multirow{2}{*}{$\begin{array}{l}\text { Age of } \\
\text { librarians }\end{array}$} & 35 to 50 & 37.5 & 39.2 & 40.2 & 39.9 \\
\cline { 2 - 7 } & $>50$ & 29.2 & 40.6 & 55.1 & 41.6 \\
\hline
\end{tabular}




\begin{tabular}{|l|l|l|l|l|l|}
\hline \multirow{2}{*}{$\begin{array}{l}\text { Library } \\
\text { science } \\
\text { major degree }\end{array}$} & Yes & 37.5 & 10.9 & 8.3 & 18.9 \\
\cline { 2 - 6 } & No & 62.5 & 89.1 & 91.7 & 81.1 \\
\hline $\begin{array}{l}\text { Full-time } \\
\text { library } \\
\text { director? }\end{array}$ & Yes & 33.3 & 7.4 & 0 & 13.6 \\
\cline { 2 - 6 } & No & 66.7 & 92.6 & 100 & 86.4 \\
\hline
\end{tabular}

\section{4 Digital Resources}

The digital and print resources indicate the service ability of school libraries in the digital environment. Regarding independent electronic reading rooms, $49.2 \%$ of the school libraries in the three regions have set up special electronic reading rooms, but that number in the eastern region is $73.7 \%, 51.8 \%$ in the central region, and only $22.1 \%$ in the western region. As for library database purchase, only $28.8 \%$ of school libraries in the three regions have purchased databases, while $62.5 \%$ have purchased database services in the eastern region, and this number in the central region and western region were $16.4 \%$ and $7.5 \%$. Regarding library websites, only $12.1 \%$ of school libraries in the three regions have their own website. That number is $28.3 \%$ in the eastern region, $6.7 \%$ in the central region, and $1.4 \%$ in the western region. Regarding office computer automation, $75.2 \%$ of the school libraries in the three regions have office automation equipment, but that number is $100 \%$ in eastern, $72.5 \%$ in the central region, and $53.2 \%$ in the western region. Regarding self-checkout machines, only $10.8 \%$ of school libraries in the three regions own self-checkout machines, while the number is $32.3 \%$ in the eastern regions, and in the central and western regions, there are no self-lending machines. Regarding electronic reading and gaming devices, only $3.2 \%$ of the school libraries in the three regions were equipped with gaming devices, while $9.7 \%$ were in the eastern region, and none in the central and western regions. From the situation of whether there is creative space, $4.9 \%$ of the three regions of the school library had set up creative space, and all of them are in the eastern region. Table 4 illustrates statistics on digital resources in libraries.

Table 4

Statistics on the Digital Resources in School Libraries

\begin{tabular}{|c|l|l|l|l|l|}
\hline $\begin{array}{c}\text { Survey } \\
\text { projects }\end{array}$ & Index & $\begin{array}{l}\text { Eastern } \\
\text { region (\%) }\end{array}$ & $\begin{array}{l}\text { Central } \\
\text { region ( \%) }\end{array}$ & $\begin{array}{l}\text { Western } \\
\text { Region ( \%) }\end{array}$ & $\begin{array}{l}\text { Cumulative } \\
(\%)\end{array}$ \\
\hline $\begin{array}{l}\text { Independent } \\
\text { electronic } \\
\text { reading room }\end{array}$ & Yes & 73.7 & 51.8 & 22.1 & 49.2 \\
\cline { 2 - 6 } & No & 26.3 & 58.2 & 77.9 & 54.1 \\
\hline \multirow{2}{*}{$\begin{array}{l}\text { Purchase } \\
\text { database }\end{array}$} & Yes & 62.5 & 16.4 & 7.5 & 28.8 \\
\cline { 2 - 6 } & No & 37.5 & 83.6 & 92.5 & 71.2 \\
\hline
\end{tabular}




\begin{tabular}{|l|l|l|l|l|l|}
\hline \multirow{2}{*}{$\begin{array}{l}\text { Independent } \\
\text { portal } \\
\text { website }\end{array}$} & Yes & 28.3 & 6.7 & 1.4 & 12.1 \\
\cline { 2 - 6 } & No & 71.7 & 93.3 & 98.6 & 87.9 \\
\hline \multirow{2}{*}{$\begin{array}{l}\text { Automation } \\
\text { system }\end{array}$} & Yes & 100 & 72.5 & 53.2 & 75.2 \\
\cline { 2 - 6 } & No & 0 & 27.5 & 46.8 & 24.8 \\
\hline \multirow{2}{*}{$\begin{array}{l}\text { Self-lending } \\
\text { machine }\end{array}$} & Yes & 32.3 & 0 & 0 & 10.8 \\
\cline { 2 - 6 } & No & 77.7 & 100 & 100 & 92.6 \\
\hline $\begin{array}{l}\text { Electronic } \\
\text { reading and } \\
\text { gaming } \\
\text { devices }\end{array}$ & Yes & 9.6 & 0 & 0 & 3.2 \\
\cline { 2 - 6 } & No & 91.4 & 100 & 100 & 97.1 \\
\hline $\begin{array}{l}\text { Creative } \\
\text { space (3D } \\
\text { printing, } \\
\text { creator space, } \\
\text { etc.) }\end{array}$ & Yes & 14.8 & 0 & 0 & 4.9 \\
\cline { 2 - 6 } & No & 85.2 & 100 & 100 & 95.1 \\
\hline
\end{tabular}

\section{Discussion}

Surveys on 72 school libraries in 6 provinces across 3 regions in China provided baseline data to compare and analyze the current situation of school libraries in China. Although the development of school libraries in China has started, the big gap between three regions suggests that the core values and concepts of the school library profession have not been defined clearly, and the role of library services to literacy literacy has not been recognized by the society. At the same time, the lack of resources in school libraries suggested they cannot be closely integrated with the current changing social environment and educational concepts. Most importantly, the development gap between the eastern region and the central and western regions will hinder the education, critical thinking, and future workforce development at great risk. There is no way the western region can catch up to the national average without more investment from society on education.

The preliminary data suggested school libraries in China have limited buildings and their space allocation is insufficient. From our survey data, almost half of the school libraries do not have independent building space; many school libraries basically share the space with other departments of the school. In central and western regions, about one-third of the school libraries' space are less than 100 square meters. At the same time, the number of seats in the reading room is significantly inadequate, with about one-fifth of the reading room seats in the three regions' libraries are less than 10, and about one-third of the school libraries' collections per person are less than 10 . 
From the service situation, school libraries in China did not provide adequate services for teachers and students. Almost half of the libraries we surveyed did not offer a library card for the students and teachers of the school, and more than half of them borrowed less than 25 books a year per person. Other examples are nearly half of the libraries' open less than 40 hours weekly, and about 80 percent of them did not provide information literacy education for their students, and about half of the libraries do not hold reading promotion activities on campus.

School librarian's professional education is desperately needed. For example one-fifth of the school libraries have full-time librarians in less than 2, while one-fifth graduated from high school, and $80 \%$ of the school librarians do not have a library science degree, only about $15 \%$ of the library have full-time directors.

From the survey on the digital resources of school libraries in China, their development and service capacity in the electronic environment is low, and almost half of the libraries do not have an independent electronic reading room, about $70 \%$ of the libraries have not purchased database services, and only about $10 \%$ of the library has its own website. Although 80 per cent of the libraries use office automation systems, $90 \%$ of school libraries in China are not equipped with self-checkout and lending machines, electronic reading terminals, game equipment, and creative production space, especially in the western region, where there are few school libraries.

There are limitations of this study. Firstly, the sample size is small and cannot be generalized to the national population. Secondly, without interview data, there are lots of unanswered questions on what had happened and why things happened in the Chinese school libraries, and there are still many problems worthy of in-depth discussion. The future research can further carry out a more comprehensive and in-depth investigation into the school library in China, to explore the impact of the test-oriented education model on the development of Chinese school library, and how international organizations such as International Association of School Librarianship can support Chinese librarian development, and further study the school library service standard across the countries.

The speed of the development of Chinese school libraries does not keep pace with its socio-economic and cultural development, and adds a potential risk to sustainable economic growth. Chinese school libraries have not formed their own professional association yet, and there is no consistent explanation for the core competence and value of school library services, and most of the time it is guided by the policy of government bureaucracies. At the same time, there is no effective cooperation with the stakeholders of the development of the school library, resulting in the professional networking and professional development of school libraries appears to be isolated, and without connection to the outside world. Although primary and middle-school libraries are an important and effective learning environment, in China, school culture and teaching practices do not take into account the contributions of school libraries. Under the 
mission of educational and information needs of schools, school librarians may even have an image of low service quality which makes the library less appealing to school administrators, the resource allocation to the school library may be ignored by the society.

Currently there are no national or regional accreditation agencies for libraries in China. The Library Society of China (www.lsc.org.cn) is the official national non-profit library society that is registered at the Chinese Ministry of Civil Affairs. One of its subdivisions of the Library Society of China is the School Library Division, which sponsors conferences and continuing education events for school librarians. Future collaboration between the Chinese school library associations and international agencies such as IASL, can be a great venue to improve leadership for Chinese school librarians.

\section{References}

Hartzell, G. (2002). The principal's perceptions of school libraries and teacher-librarians. School Libraries Worldwide, 8(1), 92-110.

Hartzell, G. (2012). The need to shift and widen school library advocacy efforts. Library Media Connection, 30(6), 12-13.

Miao, Y. (1991). The investigation of present situation and the study of development of school libraries of China. The Proceedings of 20th Annual Conference of the International Association of School Librarianship. Everett, Washington, July 22-27, 1991, 118-123.

Wei, Z., Jiang, G., Niu T. (2013). A tale of two counties: How two school libraries in rural western China serve local needs. Library Trends, 62(1), 205-233.

Zhang, W., Wang, H., \& Ji, M. (2016). A Preliminary research study on the library collections and services of public primary and middle schools in Guangzhou, China. Canadian Journal of Information and Library Science, 40(3), 254-285.

Zhang, J., Lin, L., \& Madden, A. D. (2019). On the applicability of IFLA standards in different local contexts: The case of IFLA School Library Guidelines in China. Library Quarterly, 89(3), 232-253.

Yi, H., Mo, D., Wang, H. (2018). Do resources matter? Effects of an in-class library project on student independent reading habits in primary schools in rural China. Reading Research Quarterly, 54(3), 383-411. 


\section{Appendix A. \\ Questionnaire}

The purpose of this interview is to assess the development status of your school library. If you have any questions during the interview, you can ask me at any time.

\section{Basics of Library Statistics}

1. Building area of library:

$\square<100 \mathrm{~m}^{2} \square 101$ to $400 \mathrm{~m}^{2} \square 401$ to $600 \mathrm{~m}^{2}$

$\square 601$ to $800 \mathrm{~m}^{2} \quad \square>800 \mathrm{~m}^{2}$

2. Number of seats in the reading room: $\square<10 \square 11$ to $20 \square 21$ to $30 \square 31$ to $40 \square>40$

3. Whether the library is an independent building: $\square$ Yes $\square$ No

4. The number of collections per person in school: $\square<10 \quad \square 10$ to $20 \square 20$ to $30 \quad \square 30$ to $40 \quad \square>40$

\section{Library services}

5. Whether to make a library card for teachers and students: $\square$ Yes $\square$ No

6. The average number of books each person borrows each year: $\square<25 \quad \square>25$

7. Opening hours per week: $\square<40 \quad \square>40$

8. Whether to provide information literacy education: $\square$ Yes $\square$ No

9. Whether to hold reading project: $\square$ Yes $\square$ No

\section{Librarians}

10. Number of full-time librarians: $\square<2 \quad \square 2$ to $4 \quad \square>4$

11. librarian's educational level: $\square$ High school $\square$ Bachelor's degree

$\square$ Master degree and above

12. Age of librarians: $\square<35 \quad \square 35$ to $50 \quad \square>50$

13. Whether the librarians have a library science major: $\square$ Yes $\square$ No

14. Whether the library has a full-time curator: $\square$ Yes $\square$ No

\section{Digital Resources}

15. Whether have an independent electronic reading room: $\square$ Yes $\square$ No

16. Whether to purchase database: $\square$ Yes $\square$ No

17. Whether have an independent portal website: $\square$ Yes $\square$ No

18. Whether equip office automation system: $\square$ Yes $\square$ No

19. Whether equip a self-lending machine: $\square$ Yes $\square$ No

20. Whether provide electronic reading and gaming equipment: $\square$ Yes $\square$ No

21. Whether provide Creative space (like 3D printing, creator space, etc.): $\square$ Yes $\square$ No 